\title{
Numbers Talk Loud? A Case In Making Investment Decisions
}

\author{
Songtao Mo, Purdue University Calumet, USA
}

\begin{abstract}
This study presents a case study intended for use in the introductory financial accounting course at the undergraduate level. The case study is designed for students to evaluate accounting information in the investment decision-making process. The project aims to stimulate student interest in accounting by presenting the application of accounting information.
\end{abstract}

Keywords: Financial Accounting Information; Investment Decision

\section{INTRODUCTION}

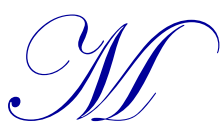

s. Kitty Fashion is the sole owner of a small consulting firm "Fashion Consulting" specialized in marketing strategies for the apparel industry. Ms. Fashion has a Bachelor's degree in Marketing from a prestigious university and she also earned an MBA with a concentration in general management from the same university.

In summer 2010, Ms. Fashion started to promote her consulting services using a new fee structure. Under the new system, Fashion Consulting would collect a very small portion of the consulting fees in cash. Stock market regulations permitting, Fashion Consulting would accept a considerate percentage of fee payment in the format of stocks on the contract date, and hold the stocks for at least two years. The new fee structure, which makes Fashion Consulting a stakeholder of clients, aims to better align the interests of Fashion Consulting and potential clients. In other words, when approached by a potential client, Fashion Consulting is also in the process of making a long-term investment decision.

Table 1: Apparel Stores and Basic Information

\begin{tabular}{|c|c|c|c|}
\hline & Company Name & Company Website & Brand Store \\
\hline \multirow{2}{*}{1} & \multirow{2}{*}{ Abercrombie\& Fitch } & \multirow{2}{*}{ http://www.abercrombie.com } & Abercrombie \& Fitch \\
\hline & & & Holister \\
\hline 2 & Aeropostale, Inc. & http://www.aeropostale.com & Aeropostale \\
\hline 3 & American Eagle Outfitters, Inc. & http://www.ae.com & American Eagle \\
\hline \multirow{2}{*}{4} & \multirow{2}{*}{ Ann Taylor Stores Corp. } & \multirow{2}{*}{ http://www.anntaylor.com } & Ann Taylor \\
\hline & & & Ann Taylor Loft \\
\hline \multirow{3}{*}{5} & \multirow{3}{*}{ Gap Inc. } & \multirow{3}{*}{ http://www.gapinc.com } & Old Navy \\
\hline & & & Gap \\
\hline & & & Banana Republic \\
\hline 6 & J. Crew Group Inc. & http://www.jcrew.com & J.Crew \\
\hline \multirow{3}{*}{7} & \multirow{3}{*}{ Limited Brands, Inc. } & \multirow{3}{*}{ http://www.limitedbrands.com } & Express \\
\hline & & & The Limited \\
\hline & & & Victoria Secrets \\
\hline 8 & Talbots, Inc. & http://www.talbots.com & Talbots \\
\hline
\end{tabular}


The new fee structure established a revised image of Fashion Consulting as both a service provider and an investor with greater incentives to enhance market value of clients. Among numerous potential clients, Ms. Fashion selected those apparel companies listed in the New York Stock Exchange (NYSE) and compiled a table containing eight apparel companies for further consideration (Table 1). After preliminary discussions, those companies also showed keen interest in Ms. Fashion's business proposals. Table 2 presents more information of those eight companies, such as a corporate website, major brand(s), index memberships, and the number of employees as of August 2010. Due to resource constraints, Fashion Consulting was only able to work with three companies simultaneously. As a result, Ms. Kitty needed to select three out of eight companies that would be worthy of both investment and business.

Ms. Fashion took a few basic accounting and finance courses when she pursued her undergraduate and graduate degrees in business. Though she was very good at designing marketing strategies, Ms. Fashion was not confident that her way of decision-making was a good one. To simplify the decision process, Ms. Fashion decided to take a two-step approach - that is, she would focus on making an investment decision first, then move on to make an integrated investment-business decision.

Table 2: Apparel Stores and Market Information

\begin{tabular}{|c|c|c|c|c|c|c|c|}
\hline & Company Name & Exchange & Ticker & $\begin{array}{l}\text { Full Time } \\
\text { Employees }\end{array}$ & Index Membership & $\begin{array}{l}\text { Fiscal Year } \\
\text { End }\end{array}$ & $\begin{array}{l}\text { Two Most Recent } \\
\text { Years }\end{array}$ \\
\hline \multirow{2}{*}{1} & \multirow{2}{*}{ Abercrombie\& Fitch } & \multirow{2}{*}{ NYSE } & \multirow{2}{*}{ ANF } & \multirow{2}{*}{9000} & S\&P 500 & \multirow{2}{*}{ 31-Jan } & \multirow{2}{*}{2009 and 2008} \\
\hline & & & & & S\&P 1500 Super Comp & & \\
\hline \multirow{2}{*}{2} & \multirow{2}{*}{ Aeropostale, Inc. } & \multirow{2}{*}{ NYSE } & \multirow{2}{*}{ ARO } & \multirow{2}{*}{3,656} & S\&P 400 MidCap & \multirow{2}{*}{ 31-Jan } & \multirow{2}{*}{2009 and 2008} \\
\hline & & & & & S\&P 1500 Super Comp & & \\
\hline \multirow{2}{*}{3} & \multirow{2}{*}{$\begin{array}{l}\text { American Eagle Outfitters, } \\
\text { Inc }\end{array}$} & \multirow{2}{*}{ NYSE } & \multirow{2}{*}{ AEO } & \multirow{2}{*}{6400} & S\&P 400 MidCap & \multirow{2}{*}{$2-\mathrm{Feb}$} & \multirow{2}{*}{2009 and 2008} \\
\hline & & & & & S\&P 1500 Super Comp & & \\
\hline \multirow{2}{*}{4} & \multirow{2}{*}{ Ann Taylor Stores Corp. } & \multirow{2}{*}{ NYSE } & \multirow{2}{*}{ ANN } & \multirow{2}{*}{3,400} & S\&P 400 MidCap & \multirow{2}{*}{ 29-Jan } & \multirow{2}{*}{2009 and 2008} \\
\hline & & & & & S\&P 1500 Super Comp & & \\
\hline \multirow{2}{*}{5} & \multirow{2}{*}{ Gap Inc . } & \multirow{2}{*}{ NYSE } & \multirow{2}{*}{ GPS } & \multirow{2}{*}{135,000} & S\&P 500 & \multirow{2}{*}{ 31-Jan } & \multirow{2}{*}{2009 and 2008} \\
\hline & & & & & S\&P 1500 Super Comp & & \\
\hline \multirow{2}{*}{6} & \multirow{2}{*}{ J. Crew Group Inc } & NYCF & ICC & 3400 & S\&P 400 MidCap & 21 Ion $>$ & 2000 and 200 e \\
\hline & & NYSE & $\pi(U$ & 3,400 & S\&P 1500 Super Comp & $31-\mathrm{Jan}$ & 2009 and 2008 \\
\hline 7 & I imited Rrands Jps & NYSE & ITD & 17100 & S\&P 500 & 31 Jan & 2000 and 2008 \\
\hline 1 & Limited Brands, Inc. & NYSE & LID & 17,100 & S\&P 1500 Super Comp & $31-J a n$ & 2009 and 2008 \\
\hline 8 & Talbots, Inc. & NYSE & TLB & 3,400 & N/A & 30-Jan & 2009 and 2008 \\
\hline
\end{tabular}

\section{KITTY FASHION'S INVESTMENT DECISION}

Ms. Fashion's analysis assumed that the eight companies were equally good consulting clients. Fashion Consulting did not have a cash flow issue so Ms. Fashion planned to consider the investments of consulting fees as a long term investment. Additionally, Ms. Fashion would like to maintain a steady income in the long run and did not intent to take unnecessary risks. Therefore, in the prediction of the stock price trend, Ms. Fashion started with ratio analysis and examined the profitability, financial leverage, and other applicable ratios. Table 3 provides two years' ratios for her preliminary analysis.

Ms. Fashion first examined the profitability ratio. As illustrated in Table 3, most profitability indices of both ANN (Ann Taylor) and TLB (Talbots) were negative. Specifically, profit margin, return on assets (ROA), return on stockholders' equity (ROE), earnings per share (EPS), and price-earnings (P/E) ratios in 2009 and 2008 were all negative. The ratios indicated that ANN and TLB were in a bad situation for two consecutive years. 
Furthermore, ANF (Abercrombie \& Fitch) had reasonable profitability ratios in year 2008 but all the numbers deteriorated in year 2009. The analysis suggested that investment in ANF might bear higher risk than necessary.

Table 3: Comparative Analysis of Financial Ratios

\begin{tabular}{|c|c|c|c|c|c|c|c|c|c|}
\hline \multicolumn{10}{|c|}{ Panel A: Financial Ratios of Fiscal Year 2008} \\
\hline Financial Ratios & & ANF & ARO & AEO & ANN & GPS & JCG & LTD & TLB \\
\hline \multicolumn{10}{|l|}{ Liquidity Ratios } \\
\hline Current Ratio & Current Assets / Current Liabilities & 2.38 & 2.25 & 2.30 & 1.39 & 1.86 & 1.88 & 1.55 & 0.98 \\
\hline Acid-test Ratio & (Cash=Short Term Investments +Receivables(Net)/Current Liablities & 0.12 & 1.30 & 0.13 & 0.05 & 0.00 & 0.70 & 1.12 & 0.29 \\
\hline Inventory Turnover & Cost of Goods Sold / Average Inventory & 3.10 & 9.74 & 6.15 & 6.57 & 6.03 & 7.63 & $(5.11)$ & 5.08 \\
\hline \multicolumn{10}{|l|}{ Profitability Ratios } \\
\hline Profit Margin & Net Income/Net Sales & 0.08 & 0.08 & 0.06 & $(0.15)$ & 0.07 & 0.04 & 0.02 & $(0.02)$ \\
\hline Asset Turnover & Net Sales / Average Assets & 1.28 & 3.22 & 2.00 & 1.86 & 1.89 & 2.41 & 1.26 & 1.00 \\
\hline Return on Assets & Net Income/ Average Assets & 0.10 & 0.25 & 0.12 & $(0.28)$ & 0.13 & 0.09 & 0.03 & $(0.02)$ \\
\hline Return on Stockholders' Equity & Net Income / Average Common Stockholders' Equity & 0.16 & 0.54 & 0.13 & $(0.53)$ & 0.22 & 0.30 & 0.11 & $(0.21)$ \\
\hline Earnings Per Share (EPS) & Net Income / Weighted Average Common Shares Outstanding & 3.14 & 1.49 & 0.87 & $(5.82)$ & 1.35 & 0.85 & 0.66 & $(10.41)$ \\
\hline Price-Earning Ratio & Market Price per Share of Stock / EPS & 5.68 & 14.17 & 10.26 & $(0.94)$ & 8.36 & 11.76 & 12.00 & $(0.20)$ \\
\hline \multicolumn{10}{|l|}{ Solvency Ratios } \\
\hline Debt to total assets ratio & Total Debt / Total Assets & 0.35 & 0.46 & 0.28 & 0.57 & 0.42 & 0.63 & 0.73 & 1.18 \\
\hline Times Interest Earned & Income before income taxes and interest expense / Interest Expense & 146.55 & 41.38 & 167.86 & $(254.20)$ & 1548.00 & 16.28 & 3.25 & $(4.78)$ \\
\hline \multicolumn{10}{|c|}{ Panel A:Financial Ratios of Fiscal Year 2009} \\
\hline Financial Ratios & & ANF & ARO & AEO & ANN & GPS & JCG & LTD & TLB \\
\hline \multicolumn{10}{|l|}{ Liquidity Ratios } \\
\hline Current Ratio & Current Assets / Current Liabilities & 2.75 & 2.19 & 2.85 & 1.83 & 2.19 & 2.21 & 1.25 & 0.65 \\
\hline Acid-test Ratio & (Cash=Short Term Investments +Receivables(Net)/Current Liablities & 0.27 & 1.43 & 0.10 & 0.09 & 0.11 & 1.27 & 1.53 & 0.19 \\
\hline Inventory Turnover & Cost of Goods Sold / Average Inventory & 3.36 & 10.40 & 5.61 & 4.93 & 5.74 & 8.30 & $(5.40)$ & 5.76 \\
\hline \multicolumn{10}{|l|}{ Profitability Ratios } \\
\hline Profit Margin & Net Income/Net Sales & 0.00 & 0.10 & 0.06 & $(0.01)$ & 0.08 & 0.08 & 0.05 & $(0.02)$ \\
\hline Asset Turnover & Net Sales / Average Assets & 1.03 & 3.08 & 1.46 & 3.62 & 1.83 & 2.28 & 1.16 & 1.38 \\
\hline Return on Assets & Net Income/ Average Assets & 0.00 & 0.32 & 0.08 & $(0.04)$ & 0.14 & 0.18 & 0.06 & $(0.03)$ \\
\hline Return on Stockholders' Equity & Net Income / Average Common Stockholders' Equity & 0.00 & 0.58 & 0.11 & $(0.04)$ & 0.24 & 0.41 & 0.22 & 0.16 \\
\hline Earnings Per Share (EPS) & Net Income / Weighted Average Common Shares Outstanding & 0.00 & 2.30 & 0.82 & $(0.32)$ & 1.59 & 1.97 & 1.39 & $(0.55)$ \\
\hline Price-Earning Ratio & Market Price per Share of Stock / EPS & 0.00 & 14.30 & 20.37 & $(39.25)$ & 12.00 & 19.90 & 13.68 & (20.47) \\
\hline \multicolumn{10}{|l|}{ Solvency Ratios } \\
\hline Debt to total assets ratio & Total Debt / Total Assets & 0.18 & 0.45 & 0.21 & 0.48 & 0.39 & 0.49 & 0.70 & 1.22 \\
\hline Times Interest Earned & Income before income taxes and interest expense / Interest Expense & 17.87 & 956.71 & 181.01 & $(7.75)$ & 302.50 & 39.24 & 3.66 & (0.31) \\
\hline
\end{tabular}

Notes:

1. The formulas of computing financial ratios were adopted from Weygandt et al. (2007).

2. The accounting numbers used in computation were hand-collected from forms $10-\mathrm{K}$, retrieved from the EDGAR system at the SEC website.

3. Numbers in parentheses represent negative numbers.

4. Some of the numbers were shown as "0" due to space constraints, e.g., the profit margin of ANF in 2009 is 0.0000867 , but was shown as 0 because two decimal places were kept for the table illustration. Those numbers were small and they did not affect the overall analysis. 
After eliminating ANN, TLB, and ANF, Ms. Fashion further compared the remaining 5 companies by sorting the individual profitability ratios. The ROA, ROE and P/E ratios of the five candidate companies are listed from high to low as below:

ROA (Return on Assets): $A R O-J C G-G P S-A E O-L T D$

ROE (Return on Equity): $A R O-J C G-G P S-L T D-A E O$

P/E (Price-Earning Ratio): $A R O-J C G-G P S-L T D-A E O$

Ms. Fashion noticed that the profitability ratios of the first three companies (ARO, JCG and GPS) went up from 2008 to 2009. Based on her analysis, Ms. Fashion decided that ARO, JCG and GPS would be the final three choices for further consideration to make an integrated decision.

\section{DISCUSSION QUESTIONS}

1. Please evaluate Ms. Fashion's analysis. List the strengths and weaknesses of her analysis of financial accounting information.

2. Within the field of financial statement analysis, do you think Ms. Fashion's analysis is sufficient to support her investment decision? Please elaborate on your underlying reasons.

3. What further analysis, if any, would you suggest for Fashion Consulting (Ms. Fashion) to make the investment decision? Please describe your suggestions in detail.

4. In your opinion, do numbers from financial statements provide useful information in the investment decision-making process? Why and how?

\section{SUMMARY}

This study presents an instructional case constructed in a setting that the students may feel interesting and practical. The case intends to provide an opportunity for students to evaluate firm performance using accounting information retrieved from annual reports, and to integrate financial accounting concepts with decision-making skills.

The American Institute of Certified Public Accountants (AICPA) developed the core competency framework and identified three competencies, namely, functional competencies, personal competencies, and broad business perspective competencies. Decision modeling, decision making, and critical thinking are identified as important skills for these three competencies, respectively. Regardless, many students come to the introductory financial accounting course with the impression that it is a tedious and time consuming course. Another misconception is that financial accounting is only about number crunching. Most of the end-of-chapter problems focus on the problem solving skills required, yet little coverage is offered to provide a "big picture" of the importance of accounting fundamentals in daily life. This study is designed to show students the application of accounting knowledge in the equity market, and how accounting fundamentals may help in making investment decisions.

\section{AUTHOR INFORMATION}

Songtao Mo, Ph.D., is an Assistant Professor of Accounting in the School of Management at Purdue University Calumet. Her research focuses on financial reporting, intangibles, and auditing. Her teaching interests include auditing and financial accounting. She received her Ph.D. in Management with specialization in Accounting from Case Western Reserve University in 2009. Dr. Mo holds the professional designation of Certified Fraud Examiner. E-mail: $\underline{\text { smo@purduecal.edu }}$ 


\section{REFERENCES}

1. American Institute of Certified Public Accountants. (2000). Core Competency Framework for Entry into the Accounting Profession. Retrieved from www.aicpa.org.

2. Weygandt, J. J., Kimmel, P. D., \& Kieso, D. E. (2007). Financial Accounting, $6^{\text {th }}$ Edition. John Wiley \& Sons, Inc. 


\section{TEACHING NOTES}

\section{Learning Objectives and Suggested Use of the Case}

According to Weygandt et al. (2007), "investors (owners) use accounting information to make decisions to buy, hold, or sell stock." Accordingly, this study presents a project in the form of a case study, which may be used in financial accounting courses to offer students an opportunity to obtain a more in-depth understanding of accounting information and its applications. Computing financial ratios and understanding the interrelationships of various accounts is part of the understanding of the financial statement analysis. The analysis should include an assessment of a firm's financial performance over the period of time (vertical) and relative to its competitor (horizontal). Moreover, a thorough analysis of accounting data should involve interpretation of the results

This case can be used as a supplemental exercise when instructing financial ratios in financial accounting. The learning objective of this case is for students to evaluate firm performance through a comprehensive financial statement analysis. The use of groups is highly recommended for this project. Each group may prepare a professional memorandum (with attachments) based on the comparative analysis of the companies.

\section{Evaluation of Student Approaches}

Ms. Fashion's analysis was preliminary but a good starting point. Yet there exists plenty of room for students to explore the interrelationships among items from financial statements. Students should be aware of the fact that Ms. Fashion only used profitability ratios and she did not pay attention to other ratios (e.g., financial ratios, solvency ratios, etc). It is imperative for students to understand that the long-term health of a company should normally be assessed from different, yet interrelated perspectives. Students are encouraged to provide analysis from various other aspects other than accounting data. For instance, students may review the profile of the companies such as major industry, major brands offered by the companies, and target customers. Further examination may extend to the major strengths and weaknesses of the firm relative to its competitors and industry benchmark. Students should also be able to describe the impact of the overall economic environment and the stock market. Students may ask the following questions regarding stock market - Did the companies outperform or underperform the market? Will the companies outperform or underperform the market index?

The choice of apparel companies that carry brands of interest to teenagers and young professionals was to stimulate students' interest in accounting using daily life examples. The use of real world companies was intended to encourage students to research possible resources beyond the textbook and this case study. Students have the option to retrieve further information from other sources for their analysis.

Students may make valid assumptions and come up with different investment decisions. Instructors may evaluate the students' analysis based on several criteria, including but not limited to thoroughness of discussion, evidence of critical thinking, adequacy of support for claims and statements, and the depth of extra research. Students are encouraged to revisit their results one year later and reflect on their investment decisions. 